\title{
Are homeowners willing to adapt to and mitigate the effects of climate change?
}

\section{Erik Bichard \& Aleksandra Kazmierczak}

\section{Climatic Change}

An Interdisciplinary, International Journal Devoted to the Description, Causes and Implications of Climatic Change

\section{ISSN 0165-0009}

Volume 112

Combined 3-4

Climatic Change (2012) 112:633-654

DOI 10.1007/s10584-011-0257-8

\section{Climatic Change}

An Interdisciplinary, International Journal Devoted to the Description, Causes and Implications of Climatic Change Co-Editors: MICHAEL OPPENHEIMER
GARY YOHE

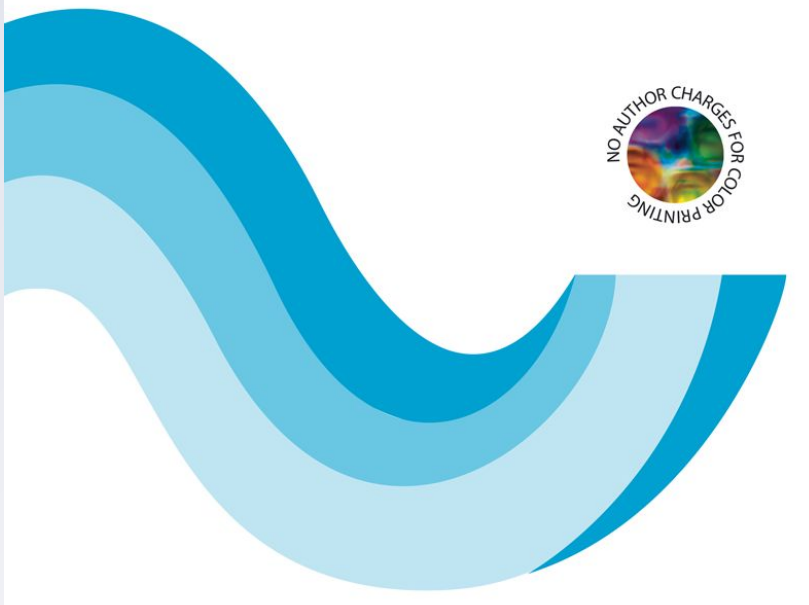

ISSN 0165-0009 黛 Springer

Springer 
Your article is protected by copyright and all rights are held exclusively by Springer Science+Business Media B.V.. This e-offprint is for personal use only and shall not be selfarchived in electronic repositories. If you wish to self-archive your work, please use the accepted author's version for posting to your own website or your institution's repository. You may further deposit the accepted author's version on a funder's repository at a funder's request, provided it is not made publicly available until 12 months after publication. 


\title{
Are homeowners willing to adapt to and mitigate the effects of climate change?
}

\author{
Erik Bichard • Aleksandra Kazmierczak
}

Received: 21 September 2009 / Accepted: 31 August 2011 /Published online: 1 October 2011

(C) Springer Science+Business Media B.V. 2011

\begin{abstract}
The need to adapt to climate change impacts, whilst simultaneously limiting greenhouse gas emissions, requires that the government's efforts are joined by public action. In England and Wales, housing contributes significantly to the emissions and many properties are at risk of flooding. This paper investigates the preparedness of homeowners in England and Wales to make changes to their homes in response to the predicted effects of climate change. A telephone survey of 961 homeowners investigated their interest in purchasing mitigation and adaptation improvements against their concern about climate change, awareness of flood risk and attribution of responsibility for action. Whilst the majority of homes had some energy-saving improvements, few were found to have property-level flood protection. The high levels of awareness about climate change and flooding were coupled with the perception of risks as low. Whilst some respondents accepted personal responsibility for action, most believed that the authorities were responsible for flood protection, and would not pay the costs required to make their home more energy-efficient and better prepared for the eventuality of floods. The results suggest that there is scope for further improvement of energy-saving measures, and that the levels of adoption of flood-protection measures are very low. Multi-faceted strategies, including more effective communication of risks and responsibilities, incentives, and material support for the poorest, will need to be developed to overcome the current reluctance by homeowners to invest in flood-protection measures and further energy conservation solutions in the future.
\end{abstract}

\section{Introduction}

Climate scientists suggest that the threshold of the global mean temperature increase resulting in significant or substantial consequences is much lower than previously estimated

E. Bichard $(\bowtie)$

School of the Built Environment, University of Salford, Maxwell Building, The Crescent, M5 4WT Salford, UK

e-mail: e.bichard@salford.ac.uk

A. Kazmierczak

School of Environment and Development, University of Manchester, Humanities Bridgeford Street Building, Oxford Road, M13 9PL Manchester, UK 
(Smith et al. 2009). In light of the continuing growth in emissions of greenhouse gases, there is an urgent need to double the efforts aimed at both mitigation and adaptation to climate change in order to reduce the scale of the damage. For individual properties, a reduction in the severity of impacts at property level can be achieved by decreasing the amount of energy used and by protecting the structure against extreme events such as flooding.

Until recently, the UK Government's messages on dealing with climate change have almost exclusively emphasised mitigation measures. The Climate Change Act 2008 placed legally binding limits on greenhouse gas emissions and it has been identified that individual members of the public need to reduce their carbon emissions in order to achieve these targets (HM Government 2006). There have been a number of public and private sector campaigns seeking to motivate the public to use less energy at home (Boardman 2004; Ofgem 2008). Yet, despite government messages, many millions of homes in the UK are not energy-efficient due to under insulation and old heaters or appliances (DECC 2010a).

In comparison to mitigation measures, improvements which could make the housing better adapted to the impacts of extreme weather and climate change are less well-established (Sanders and Phillipson 2003; Three Regions Climate Change Group 2008) and far less effort has been directed at motivating the public to adapt their properties. However, individuals are increasingly being seen by policymakers as needing to take personal responsibility to protect their dwellings against the effects of flooding (Pitt 2008). In "Making Space for Water", the government (DEFRA 2004) emphasised a change to the flood risk management paradigm away from a previously state-centred approach towards one in which other organisations and individuals take a more prominent role (Johnson and Priest 2008).

Consequently, wider implementation of property-level climate change adaptation and mitigation methods is necessary in the domestic sector. This study investigates the preparedness of householders in England and Wales to install and pay for energy conservation and floodprotection measures in their homes, in association with their awareness of climate change and its impacts and their stated levels of responsibility for taking action. This helps to draw conclusions about the possible reasons for low implementation of the adaptation and mitigation improvements and provides some policy recommendations for government bodies wishing to accelerate property-level investment in privately owned homes.

\section{Current uptake of mitigation and adaptation measures}

\subsection{Energy-saving measures}

The domestic built environment accounts for around $27 \%$ of UK emissions (HM Government 2006). As over $80 \%$ of existing buildings will still be in use in 2050 (Boardman 2007), the current housing stock will have a vital role to play in meeting the $80 \%$ reduction in greenhouse gas emissions required by the UK Climate Change Act 2008 (Clarke et al. 2008). Yet the energy efficiency of the current UK housing stock is poor (Boardman 2007); only 10\% of homes in England achieve ratings A-C on an A to G energy efficiency scale (CLG 2010). In an average British house, over half the energy is used for space heating, $20 \%$ for water heating, 16\% for electrical appliances and the remainder for lighting and cooking (HM Government 2006). Therefore, whilst changing residents' habits (such as switching lights off) is undoubtedly beneficial, the main means to reduce energy consumption in private households in timescales that fit with Climate Change Act targets will be by improving the roof space and wall insulation of existing houses and installing thermal glazing and energy-efficient heating units and appliances. 
A range of government initiatives were designed to increase the uptake of energy-saving measures. The Warm Front initiative in England between 2000 and 2008 assisted $1.7 \mathrm{~m}$ disadvantaged and older people to install central heating and double glazing (DEFRA and BERR 2008). A significant increase in the purchase of energy-efficient appliances, such as refrigerators and washing machines, has resulted from European Union policy on product standards (Boardman 2004). The Energy Efficiency Commitment of UK gas and electricity suppliers delivered $187 \mathrm{TWh}$ of energy savings, mainly due to provision of cavity wall and loft insulation (Ofgem 2008). In addition, for 15 years the government-funded Energy Saving Trust has been offering advice to householders on energy efficiency including the endorsement of products, energy audits and, more recently, support for local authorities and community groups to organise energy-saving programmes for themselves.

The uptake of energy-efficiency measures is rising steadily (CLG 2010); for example, $71 \%$ of houses in England have full double glazing, with an additional 13\% having replaced more than half their windows with double-glazed units (CLG 2010). Over 70\% of appliances purchased in England between 2007 and 2009 were claimed to carry the Energy Saving Recommended logo (DEFRA 2009a). Yet a significant amount of the UK housing stock is still missing some or all of these basic measures. In Great Britain, $47 \%$ of lofts have insulation exceeding $125 \mathrm{~mm}$ (DECC 2010a) and only 21\% of English houses in 2008 had insulation thicker than $200 \mathrm{~mm}$ (CLG 2010). In addition, 45\% of homes with cavity walls have yet to be insulated (DECC 2010a). Whilst the number of households installing energyefficient boilers has increased in recent years, by 2008 only $17 \%$ had made this investment in England (CLG 2010). This suggests that the government's policy based on awareness raising and help for the poorest and least able householders has not exhausted the potential for improvement in domestic energy efficiency.

\subsection{Property-level flood-protection measures}

One in six properties in England and Wales is threatened by flooding, amounting to an estimated 5.2 million premises in England (EA 2009a) and 357,000 in Wales (EAW 2009). In England alone, half a million properties are located in areas of annual probability of flooding higher than $1.33 \%$ (EA 2009a). Flooding in the UK is likely to become a more severe and localised phenomenon in the future due to climate change (EA 2009a; Evans et al. 2004). Already, recent decades have seen an increase in winter rainfall and heavy precipitation events (Jenkins et al. 2009), and Palmer and Räisänen (2002) estimate that, for parts of the UK, the probability of total winter precipitation exceeding two standard deviations above normal will increase by a factor of five.

The government's efforts to reduce the impact of flooding are focused around flood risk assessment, forecasting, provision of defences and warnings and awareness raising (DEFRA 2004; EA 2009a). To date, almost 70\% of England and Wales has been assessed for flood risk and the Environment Agency (EA) informs residents each time a new flood risk area has been defined (EA 2009a). The flood forecasting, which is based on measurements of river and sea levels (EA 2009a), is not available for all flood risk areas. Moreover, over half of the 5.2 million properties at risk of flooding are threatened by surface water flooding (EA 2009a), which at present is difficult to forecast with any great accuracy (Falconer et al. 2009).

Raising awareness of flood risks and empowering people living in flood risk areas to take action are main objectives of the government (DEFRA 2004; Burningham et al. 2007; EA 2009a). The EA provides online flood risk maps and free information about approaching flooding by telephone and email-Floodline Warnings Direct (FWD). In 2007-2008, 61\% of properties at risk of river and sea flooding across England and Wales 
were covered by this service and the EA is aiming to increase this to $80 \%$ by 2013 (EA 2009a). Whilst annually $£ 500$ million is spent on the maintenance and new construction of structural flood defences (EA 2009a), it is estimated that about half the households in areas of significant risk of flooding are undefended (DEFRA 2008a). Also, flood risk may be affected by the public spending reviews, which are likely to lead to a reduction in flood defence budget (ABI 2010). Therefore, for some houses, property-level measures could be the only flood protection available. In other areas it could supplement the protection afforded by structural defences.

Property-level flood-protection measures may be classified into those that increase the resistance of the house, and those that improve its resilience (DEFRA 2008a). Resistance measures are designed to keep water out of the property by sealing potential water entry points. These measures are either temporary, in which case they are applied shortly before a flood (door barriers, toilet plugs, air brick covers), or permanent (raised thresholds and floors, waterproof doors and valves on waste water pipes) (Bowker 2002). Resilience measures aim to minimise damage to the house structure, including the interior and furnishings, in the likely event that water will enter the premises, thereby facilitating the quickest possible recovery (Pitt 2008). These measures are largely permanent and include replacing floor, wall and furnishing materials with waterproof alternatives, and raising the electrical fixtures above the expected flood level (Bowker 2002).

At present, less than 5,000 homes have adopted resistance or resilience measures in the UK (DEFRA 2008a). In order to increase the uptake, in December 2008, DEFRA announced the $£ 5.5$ million Property-Level Flood Protection Grant Scheme, which offers local authorities in England the opportunity to apply for funding to identify and subsidise appropriate measures for individual properties in areas of frequent flooding and without structural defences (DEFRA 2009b). The pilot project in 2008 provided flood-protection measures to 177 residential properties (DEFRA 2008b) and the current scheme continues until March 2011.

In summary, while the UK government has in recent years sought to influence house owners to adopt energy-saving and flood-protection measures, the strategies employed to date have not been as effective as policymakers may have hoped. The challenge for policymakers in changing public behaviour towards desirable policy outcomes, such as increased uptake of energy-efficiency and flood-protection measures, is to discern which interventions will be most effective. The next section considers the conditions necessary for homeowners to install property-level adaptation and mitigation measures. Influencing these conditions may increase the implementation rate of the considered measures.

\section{Conditions for the acquisition of adaptation and mitigation measures}

\subsection{Reasoned behaviour models}

Much of the work about barriers that inhibit action in response to climate change stems from the theory of reasoned action (Ajzen and Fishbein 1980), which can be summarised as the following set of questions individuals ask themselves before acting:

- Do I understand that there is a problem?

- Do I care about the problem?

- Do I know what to do about the problem?

- Will my solution work or make a difference?

- What will others think of me if I act? 
This thinking is reflected, for example, in Grothmann and Patt's (2005: 203) theoretical "model of private proactive adaptation to climate change", developed by drawing from the literature in psychology and behavioural economics. The model starts from risk appraisal, or assessment of the probability and severity of impact. Only when the perceived threat exceeds a certain threshold does the individual carry out the adaptation appraisal, which includes an assessment of their belief in the effectiveness of the actions, the perceived ability to carry out the adaptive responses, and the perceived cost of the action. Depending on the outcomes of this appraisal, adaptation actions are implemented or not.

Similarly, Lamond and Proverbs (2009), based on a literature review of empirical studies, identified the mental steps that need to be completed by a flood plain resident who wants to implement flood-protection measures. These include awareness of the risk, the perception that the risk is sufficient to warrant action, and owning the problem rather than expecting an outside agency to solve it. Once this is achieved, the person needs knowledge of the solution, resources to implement it, and a belief that the solution is effective and beneficial. Barriers to completion of these steps may be informational, financial or emotional (denial of risks; attribution of responsibility to others) (Lamond and Proverbs 2009).

In relation to climate change mitigation, Lorenzoni et al. (2007) identified the reasons why people would not change their behaviour as lack of knowledge about the causes and consequences of and solutions to climate change, scepticism about the information, downplaying the climate change immediacy and significance, externalising responsibility and blame, reluctance to change lifestyles, and fatalism. Stern (2000) concluded that individuals will make decisions according to their state of awareness and concern about climate change, their willingness to act, and a belief that their action will be effective and beneficial.

There is, therefore, a need to investigate public understanding of the climate change problem, how people attribute responsibility for action, the extent of knowledge around solutions, and whether financial resources are a constraint. Answers to these questions should be able to guide policymakers towards better policy interventions including targeted education and awareness and different forms of economic instruments. The literature to date provides some level of understanding about the conditions for action, yet the information is scattered among many sources. The following sections outline the current understanding of the problem.

\subsection{Awareness of climate change and its risks}

The degree of understanding of climate change causes seems to be high, and has increased markedly over recent years (Lorenzoni et al. 2007; DEFRA 2009a). The predominant percentage of respondents $(85 \%)$ to the DEFRA (2009a) survey of public attitudes and behaviours towards the environment (carried out with respondents across representative parts of England) thought that climate change was caused by energy use and only $27 \%$ said they did not believe that their everyday behaviour and lifestyle contributed to climate change. Yet the risks associated with climate change impacts tend to be perceived as low and not personally relevant (Lorenzoni et al. 2006). Whilst some studies show that the majority of flood plain residents are aware of living in flood risk areas (Harries 2008; Kazmierczak and Bichard 2010), the actual risk is predominantly seen as low (Kazmierczak and Bichard 2010) or located in a distant future (Whitmarsh 2008).

In general, those who have not experienced flooding assess the future risks as lower (Burningham et al. 2007; Werritty et al. 2007; Kazmierczak and Bichard 2010). Advanced 
age tends to have a negative influence on awareness of flood risk (Burningham et al. 2007), or concern about climate change impacts and the willingness to adapt (Whitmarsh 2008; Kazmierczak and Bichard 2010). Those with higher education and income have been found to be more aware of their flood risk (Burningham et al. 2007) and more likely to buy energy-efficient appliances (Boardman et al. 1997).

The literature suggests that, whilst a majority of householders are aware that climate change is a serious issue, the potential consequences of the threats posed by climate change seem to be underestimated and misunderstood. This, alongside the relation between sociodemographic characteristics of people and their opinions, may have significant implications for shaping policy and needs to be explored further.

\subsection{Attributed responsibility for action}

The DEFRA (2009a) survey suggests that three-quarters of respondents were already proactively saving energy in their homes; only $14 \%$ said that they did not give it much thought. They were also interested in doing more in the future: installing double glazing (45\%); buying an energy-efficient boiler (14\%); insulating cavity walls $(11 \%)$ or improving existing loft insulation $(10 \%)$. However, the respondents did not see action to reduce $\mathrm{CO}_{2}$ emissions as solely their responsibility, and $59 \%$ said that they would be more motivated if government did more to tackle climate change.

More people see the government as primarily responsible for flood protection and the structural forms of defence are favoured (Werritty et al. 2007). In Scotland, less than a quarter of respondents accepted individual responsibility for flood protection, and attributing responsibility to local or central government was the main reason not to undertake any measures to protect their properties (Werritty et al. 2007). In the Netherlands, where, similar to the UK, individual flood protection has not been a subject of policy until recently, the majority of 658 surveyed householders said that both the government and individual citizens were equally responsible for preparing people for flood disaster. However, whilst $18 \%$ thought this was primarily or exclusively a personal responsibility, $73 \%$ saw the government as primarily or totally responsible for preventing flood damage to their possessions (Terpstra and Gutteling 2008).

Interestingly, only $41 \%$ of eligible households in England and $43 \%$ in Wales subscribe to FWD (Pitt 2007; WAG 2010). This may be associated with the low perception of risk (see section 3.2), but also with the wide availability of flood insurance in the UK, which is a feature of standard household policy in areas where the annual probability of flooding is lower than $1.33 \%$, under the 1961 agreement between government and the insurance industry (Crichton 2007), which lasts until 30 June 2013 (ABI 2008). Consequently, $80 \%$ of households in the UK are covered by contents insurance (Werritty et al. 2007). It is therefore likely that many homeowners do not necessarily see the need to implement flood-protection measures or register with FWD due to the certainty about compensation following flooding distorting their perception of risk (Crichton 2007; Johnson and Priest 2008). Little is known about the influence of previous experiences of flooding on the perception of responsibility for flood-protection actions, undertaken or planned, although Harries (2008) found that higher numbers of those who had been flooded previously were willing to take any action to prepare for future floods. Thus, this paper investigates the associations between the previous experience of flooding and subscription to FWD, having flood-protection measures installed and planning to install them in the future. 


\subsection{Knowledge of solutions}

Despite the Government's commitment to target better understanding about ways to mitigate climate change, $29 \%$ of respondents to the DEFRA (2009a) survey had never considered an energy-efficient boiler, $27 \%$ had never considered solid wall insulation, and $14 \%$ cavity wall insulation. This may suggest that there is still scope for education about these improvements.

The EA is attempting to increase awareness of flood resistance and resilience measures in a brochure "Prepare Your Property for Flooding" (EA 2009b), which directs readers to products in the "Blue Pages Directory" on the National Flood Forum Website (www. floodforum.org.uk). Little is known about public awareness of flood resistance and resilience measures. In Salford, very few respondents mentioned air brick covers, raising the door thresholds, sealing doors or windows or raising electrical fixtures above the likely flood level as possible solutions (Kazmierczak and Bichard 2010). This paper investigates public knowledge about property-level flood-protection solutions.

\subsection{Affordability of adaptation and mitigation measures}

The Energy Saving Trust (www.energysavingtrust.org.uk) provides some indication of typical costs of energy-saving measures: $£ 150$ for cavity wall or loft top-up insulation; $£ 1,800$ for a new energy-efficient boiler (without installation and connection charges); and $£ 2,000-4,000$ for double glazing an entire house. Whilst government estimates (DECC 2010 b) show that householders can save around $£ 45$ per year in heating bills by having thick loft insulation, and $£ 115$ per year with cavity wall insulation, (resulting in a payback time of under 2 years), even these cheaper energy-saving options can be too expensive for some. DEFRA's (2009a) survey suggests that around a quarter of the respondents could not afford cavity wall or loft insulation.

Flood-protection measures are more expensive. In the DEFRA pilot of individual floodprotection grants, the average cost of works per property was about $£ 2,900$, in a range from circa $£ 300$ to $£ 13,000$ (DEFRA 2008b). For a shallow flooding event (less than $90 \mathrm{~cm}$ ), smaller properties can be protected with resistance measures for as little as $£ 2,300$, whilst recovering from a flood may cost from $£ 4,500$ to $£ 23,000$. For deeper floods, a package of resistance measures may cost from $£ 20,000$ to $£ 40,000$, but this may still be recovered in a single flood event (Three Regions Climate Change Group 2008). Bowker (2007) observes that some measures may not cost more than standard repairs (raising electrical fixtures above the likely flood level should not exceed $£ 1,000$ ), yet a whole package of resilience measures can reach $£ 10,000$ to $£ 30,000$.

The research on preparedness to pay for flood-protection measures is limited, but the existing literature indicates that the majority of people would not pay anything (Werritty et al. 2007; Kazmierczak and Bichard 2010). Only 8.5\% of respondents to a household survey in Scotland were willing to contribute an additional $£ 100$ per year in council tax to fund flood protection (Werritty et al. 2007). A survey of over 1,500 people in England and Wales (DEFRA 2005) revealed that previously flooded or at risk respondents were willing to pay respectively $£ 200$ or $£ 150$ a year to avoid the health impacts associated with flooding. The median one-off sum respondents to a survey in Salford were prepared to pay for floodprotection measures was less than $£ 100$ (Kazmierczak and Bichard 2010). Thus, the costs of flood-protection measures seem to exceed the sums people are willing to pay for them.

In summary, whilst a large proportion of the public in England and Wales may now be familiar with climate change and accept that this phenomenon will affect their lives, many 
householders lack sufficient motivation to act on this understanding and invest in their homes. When gauged against the barriers to reasoned behaviour, acceptance of the problems is tempered by an incomplete understanding of how to respond, and an unwillingness to accept that the householders bear the responsibility for protecting their properties. More seriously, for those living in flood-threatened areas, the almost universal belief that a flood is unlikely to affect their houses make it highly challenging for regulators and policymakers to persuade property owners to spend money on an issue that they believe is a low priority. This is the context within which the attitudinal survey was designed, investigating the relationship between the conditions necessary for uptake of adaptation and mitigation measures and the willingness of homeowners to implement and pay for them.

\section{Methods}

Postcodes were selected where, according to the EA national flood risk zone data, at least $80 \%$ of properties were at risk of flooding exceeding $1.33 \%$ annual probability and the remaining properties had over $0.5 \%$ annual probability of being flooded. The postcodes where fewer than $50 \%$ of households were owner-occupied (based on Mosaic data; Experian 2009) were excluded. The research focused on homeowners because, in contrast to private rental and social housing tenants, they have direct control over their property. Further, owner-occupied dwellings form over two-thirds of the housing stock in England and Wales (LGDU 2008; CLG 2010), and therefore offer the greatest potential for energy-saving and damage-reducing actions.

A random sample of 11,584 addresses in the predominantly owner-occupied postcodes was selected for the telephone survey. The aim was not to create a statistically representative sample but rather to provide adequate coverage of the most salient demographic criteria. The sample was stratified according to social grades (based on census data and available for addresses listed in market research databases), which reflect the chief earner's occupation (Wilmhurst and McKay 1999), and provide a proxy for education and income. Grades A and B include managerial, administrative or professional occupations, respectively at higher and intermediate levels. Grade $\mathrm{C} 1$ includes people with jobs of a supervisory, clerical and junior managerial, administrative or professional nature. People classified to $\mathrm{C} 2$ are skilled manual workers. Grade D includes semi- and unskilled manual workers and Grade E are casual workers, pensioners and those dependent on the welfare state for their income. Clustered classifications $(\mathrm{AB}, \mathrm{C} 1, \mathrm{C} 2$ and $\mathrm{DE})$ are frequently used for market research purposes in the UK (Meier and Moy 2004), but also have been used in studies pertaining to flooding (Burningham et al. 2007; Parker et al. 2007). The sample included responses from 961 households. ${ }^{1}$

The questionnaire used in the phone interview consisted of three parts. The first part tested concerns about climate change and its impacts, with a particular focus on flooding and the attribution of responsibility for housing protection (see Table 2). It also included questions about perception and experience of flood risk and actions taken to prepare for flooding (see section 5.2). The second part of the questionnaire investigated current uptake of and future interest in five types of flood-protection improvements (Table 5) and five energy-saving measures (Table 7), followed by questions on preparedness to pay for them. The final part of the questionnaire investigated characteristics of the respondents (Table 1). The questionnaire was piloted in Salford, North West England (Kazmierczak and Bichard 2010), and is available on request.

\footnotetext{
${ }^{1}$ The exact response rate is difficult to estimate, as the interviewers encountered a very high refusal rate associated with the focus on just owner-occupiers in this study.
} 
Table 1 Characteristics of the respondents

\begin{tabular}{|c|c|c|c|c|c|c|c|}
\hline & & \multicolumn{2}{|c|}{ Total } & \multicolumn{4}{|c|}{ Social grades $(\%)$} \\
\hline & & $\mathrm{N}$ & $\%$ & $\mathrm{AB}$ & $\mathrm{C} 1$ & $\mathrm{C} 2$ & $\mathrm{DE}$ \\
\hline \multicolumn{2}{|l|}{ Total } & 961 & 100 & 27.8 & 29.8 & 20.6 & 21.9 \\
\hline \multirow[t]{5}{*}{ Age } & Under 25 & 10 & 1.0 & 1.1 & 2.1 & 0.5 & 0.0 \\
\hline & $26-39$ & 110 & 11.4 & 14.2 & 13.3 & 12.6 & 4.3 \\
\hline & $40-59$ & 369 & 38.4 & 44.2 & 42.3 & 43.9 & 20.5 \\
\hline & 60 and over & 454 & 47.2 & 39.0 & 41.3 & 41.4 & 71.4 \\
\hline & No data & 18 & 1.9 & 1.5 & 1.0 & 1.5 & 3.8 \\
\hline \multirow[t]{10}{*}{ Employment status } & Employed full-time & 315 & 32.8 & 43.1 & 39.2 & 36.9 & 7.1 \\
\hline & Employed part-time & 108 & 11.2 & 12.4 & 11.9 & 12.1 & 8.1 \\
\hline & Self-employed & 89 & 9.3 & 10.1 & 11.9 & 10.6 & 3.3 \\
\hline & In full-time education & 6 & 0.6 & 0.7 & 1.4 & 0.0 & 0.0 \\
\hline & Unemployed & 13 & 1.4 & 0.0 & 1.0 & 2.5 & 2.4 \\
\hline & Long term sick & 9 & 0.9 & 0.0 & 1.0 & 0.5 & 2.4 \\
\hline & Retired & 388 & 40.4 & 31.1 & 30.1 & 33.3 & 72.9 \\
\hline & Full-time house person & 22 & 2.3 & 1.9 & 2.4 & 2.5 & 2.4 \\
\hline & Other & 8 & 0.8 & 0.7 & 0.7 & 1.0 & 1.0 \\
\hline & No data & 3 & 0.3 & 0.0 & 0.3 & 0.5 & 0.5 \\
\hline \multirow[t]{5}{*}{ Size of the house } & 1 bedroom & 39 & 4.1 & 3.7 & 4.2 & 3.0 & 5.2 \\
\hline & 2 bedrooms & 229 & 23.8 & 20.2 & 23.1 & 26.3 & 27.1 \\
\hline & 3 bedrooms & 452 & 47.0 & 38.6 & 46.5 & 55.1 & 51.0 \\
\hline & 4 bedrooms & 182 & 18.9 & 27.0 & 19.2 & 13.1 & 13.8 \\
\hline & More than 4 bedrooms & 59 & 6.1 & 10.5 & 7.0 & 2.5 & 2.9 \\
\hline \multirow{5}{*}{$\begin{array}{l}\text { Length of residence } \\
\text { in the property }\end{array}$} & Less than 2 years & 41 & 4.3 & 4.1 & 6.3 & 3.0 & 2.9 \\
\hline & $2-5$ years & 153 & 15.9 & 20.6 & 17.8 & 12.1 & 11.0 \\
\hline & $6-10$ years & 175 & 18.2 & 19.1 & 20.6 & 17.7 & 14.3 \\
\hline & $11-20$ years & 219 & 22.8 & 26.2 & 18.9 & 24.7 & 21.9 \\
\hline & Over 20 years & 373 & 38.8 & 30.0 & 36.4 & 42.4 & 50.0 \\
\hline
\end{tabular}

Spearman's rank correlation $\left(\mathrm{r}_{\mathrm{s}}\right)$ was initially calculated for variables relating to awareness of climate change and flooding, and questions about responsibility in part 1 of the questionnaire. This inter-correlated dataset was reduced with the use of Principal Component Analysis (PCA) in order to ensure against redundancy of data. Varimax rotation was applied to maximize variance of factor loadings, and aid classification of variables. Only components with an eigenvalue larger than one were retained. Median values of ordinal variables and principal component scores were compared between unrelated samples with Mann-Whitney and Kruskall-Wallis tests.

\section{Results}

\subsection{The respondents}

The four main social grades were nearly equally represented in the sample (Table 1). Just over half the respondents were in employment, and over $40 \%$ were retired. Nearly half the 
respondents were over 60 years old. This high proportion, compared with $22 \%$ for the whole of England and Wales (ONS 2001), may be due to the demographics of owneroccupation. Government estimates $79 \%$ of people aged $55-64$ and $75 \%$ of people over 65 are owner-occupiers compared with $51.5 \%$ of $25-34$ year olds and $14.4 \%$ of 16-24 year olds (CLG 2010b). This suggests that older householders in flood risk areas may need particular consideration in relation to flood resistance and resilience solutions.

Over $60 \%$ of respondents had lived in their current neighbourhood for 11 years or longer. The age of respondents was positively correlated with the length of residence in the area $\left(\mathrm{r}_{\mathrm{s}}=0.437 ; p<0.001\right)$. The dominant size of house was three bedrooms.

\subsection{Climate change and flooding: Awareness, perceived responsibility and current preparedness}

Respondents showed high levels of concern about the effects of climate change and accepted personal responsibility for contributing to and mitigating climate change (Table 2). Whilst many were convinced that the responsibility for protection of homes against flooding lay with their owners, an almost identical distribution of answers was given in relation to a belief that it was the government's responsibility to protect houses from floods. Nearly $49 \%$ of respondents gave the same answer to these two questions, and of these $82.8 \%$ agreed with both statements and $9.7 \%$ strongly agreed, which suggests that the responsibility was largely seen as shared between the house owners and the authorities.

The majority of respondents $(82.0 \%)$ were aware that their house was located in a flood risk area, but only $17.6 \%$ had previously been affected by flooding. Despite high levels of awareness of living in a flood risk zone, most of the respondents thought that the likelihood of their house getting flooded in the future was very low $(40.1 \%)$ or low (38.4\%). Only $12.8 \%$ assessed the risk as high, and $3.2 \%$ as very high.

Awareness that use of fossil fuels changes climate was strongly correlated with concern about climate change and the conviction that using less energy can make a difference (Table 3). Previous experience of flooding was positively associated with awareness of living in a flood risk zone and the level of future risk of flooding. There were significant correlations between previous experience of flooding, concern about climate change effects, and perception that the government is responsible for protecting people's houses.

Table 2 Awareness of climate change and attribution of responsibility for flood protection $(N=961)$

Levels of agreement ${ }^{\mathrm{a}}(\%)$

$\begin{array}{llllll}1 & 2 & 3 & 4 & 5 & 6\end{array}$

I am concerned about how climate change might affect me and my

$\begin{array}{llllll}15.3 & 46.1 & 11.5 & 20.6 & 4.4 & 2.0\end{array}$ property

Using coal, oil and gas to produce energy for my home is changing the $\begin{array}{llllll}13.6 & 61.6 & 9.1 & 10.0 & 1.2 & 4.5\end{array}$ Earth's climate

Using less energy in my home will make a difference to climate change $\begin{array}{lllllll}15.7 & 62.9 & 5.3 & 13.0 & 1.5 & 1.6\end{array}$

Homeowners are responsible for protecting their house from flooding $\begin{array}{llllllll}16.6 & 60.0 & 8.8 & 11.6 & 1.4 & 1.7\end{array}$

The government is responsible for protecting properties against flooding $\begin{array}{lllllll}15.6 & 58.8 & 7.8 & 14.9 & 1.8 & 1.2\end{array}$

${ }^{a} 1$ - strongly agree; 2 - agree; 3 - neither agree nor disagree; 4 - disagree; 5 —strongly disagree; 6-don't know 
Table 3 Spearman's rank correlation between variables explaining perceptions of climate change, the awareness and perceived risk of flooding, and the attribution of responsibility $(N=826)$

\begin{tabular}{|c|c|c|c|c|c|c|c|c|}
\hline No & Variables & 2 & 3 & 4 & 5 & 6 & 7 & 8 \\
\hline 1 & $\begin{array}{l}\text { I am concerned about how climate change } \\
\text { might affect me and my property }\end{array}$ & $0.438^{\mathrm{a}}$ & $0.388^{\mathrm{a}}$ & $0.174^{\mathrm{a}}$ & $0.138^{\mathrm{a}}$ & $0.264^{\mathrm{a}}$ & n.s. & $0.177^{\mathrm{a}}$ \\
\hline 2 & $\begin{array}{l}\text { Using coal, oil and gas to produce energy for } \\
\text { my home is changing the Earth's climate }\end{array}$ & 1 & $0.589^{\mathrm{a}}$ & n.s. & $0.113^{\mathrm{b}}$ & $0.153^{\mathrm{a}}$ & n.s. & $0.096^{\mathrm{b}}$ \\
\hline 3 & $\begin{array}{l}\text { Using less energy in my home will make a } \\
\text { difference to climate change }\end{array}$ & & 1.000 & n.s. & n.s. & $0.080^{\mathrm{c}}$ & $0.170^{\mathrm{a}}$ & n.s. \\
\hline 4 & $\begin{array}{l}\text { Has your house ever been affected by } \\
\text { flooding? }\end{array}$ & & & 1.000 & $0.190^{\mathrm{a}}$ & $0.313^{\mathrm{a}}$ & n.s. & $0.117^{\mathrm{b}}$ \\
\hline 5 & $\begin{array}{l}\text { Are you aware that your house is in a flood } \\
\text { risk area? }\end{array}$ & & & & 1.000 & $0.252^{\mathrm{a}}$ & n.s. & n.s. \\
\hline 6 & $\begin{array}{l}\text { What do you think the chances are that you } \\
\text { will be flooded? }\end{array}$ & & & & & 1.000 & n.s. & $0.107^{b}$ \\
\hline 7 & $\begin{array}{l}\text { Homeowners have a responsibility to protect } \\
\text { their homes from flooding }\end{array}$ & & & & & & 1.000 & n.s. \\
\hline 8 & $\begin{array}{l}\text { It is the government's responsibility to } \\
\text { protect my home from flooding }\end{array}$ & & & & & & & 1.000 \\
\hline
\end{tabular}

${ }^{\mathrm{a}}$ Significant at 0.01 level; ${ }^{\mathrm{b}}$ Significant at 0.05 level; ${ }^{\mathrm{c}}$ Significant at 0.10 level; n.s.- not significant

Principal Component Analysis led to the identification of three principal components (PCs), which explained $56.7 \%$ of variance in data. These were as follows: PC1 1 -awareness of climate change, PC2 - awareness of flood risk, and PC3 - attributed responsibility (Table 4). Higher scores for PC1 and PC2 meant greater awareness of climate change and

Table 4 Principal component loadings for analysed variables. The most significant loadings are in bold $(N=$ 826)

\begin{tabular}{|c|c|c|c|}
\hline \multirow[t]{2}{*}{ Variables } & \multicolumn{3}{|c|}{ Principal component (PC) } \\
\hline & $\begin{array}{l}\text { PC1: Awareness of } \\
\text { climate change }\end{array}$ & $\begin{array}{l}\text { PC2: Awareness } \\
\text { of flood risk }\end{array}$ & $\begin{array}{l}\mathrm{PC} 3 \text { : Attributed } \\
\text { responsibility }\end{array}$ \\
\hline $\begin{array}{l}\text { I am concerned about how climate change might } \\
\text { affect me and my property }\end{array}$ & 0.674 & 0.286 & 0.195 \\
\hline $\begin{array}{l}\text { Using coal, oil and gas to produce energy for my } \\
\text { home is changing the Earth's climate }\end{array}$ & 0.840 & 0.013 & 0.013 \\
\hline $\begin{array}{l}\text { Using less energy in my home will make a } \\
\text { difference to climate change }\end{array}$ & 0.830 & -0.099 & -0.129 \\
\hline Has your house ever been affected by flooding? & -0.043 & 0.706 & 0.056 \\
\hline $\begin{array}{l}\text { Are you aware that your house is in a flood risk } \\
\text { area? }\end{array}$ & 0.025 & 0.590 & -0.134 \\
\hline What are the chances that you will be flooded? & 0.135 & 0.737 & 0.109 \\
\hline $\begin{array}{l}\text { Homeowners have a responsibility to protect their } \\
\text { homes from flooding }\end{array}$ & 0.094 & 0.080 & -0.741 \\
\hline $\begin{array}{l}\text { It is the government's responsibility to protect my } \\
\text { home from flooding }\end{array}$ & 0.116 & 0.084 & 0.716 \\
\hline$\%$ variance explained & 23.647 & 18.706 & 14.374 \\
\hline
\end{tabular}


flood risk, respectively. High values of PC3 indicated that the predominant responsibility for flood protection was attributed to the government.

The Kruskall-Wallis test comparing the principal component scores between different age and social grade groups suggested that the older respondents were, the lower their awareness of climate change (PC1) was $(\mathrm{H}=18.687 ; p<0.001)$. The other differences between mean rank values of principal component scores for age and social grade were not statistically significant.

Nearly $73 \%$ of respondents said they were insured against flooding $(14.1 \%$ did not know; $13 \%$ said they were not insured). There was a significantly lower uptake of flood insurance among respondents from social grade $\mathrm{DE}(64.7 \%)$ in comparison to other groups (73.0\% in $\mathrm{C} 1 ; 76.0 \%$ in $\mathrm{C} 2$ and $\mathrm{AB} ; \mathrm{H}=10.906 ; p<0.05)$. Nearly $43 \%$ of respondents were subscribers to FWD. The older respondents were more likely to have subscribed to the scheme $(H=11.760 ; p<0.01)$. Fewer than $21 \%$ of respondents did not know about FWD and $37 \%$ chose not to subscribe, largely due to the belief that the risk of flooding was not substantial (36\%), but also for "no particular reason" (34\%); a lack of time (11\%); and insufficient knowledge about the scheme (6\%).

The Mann-Whitney test suggests significantly higher mean rank scores of PC1 (awareness of climate change) among those who had flood insurance than among the uninsured $(\mathrm{U}=24592.0 ; p<0.001)$. The levels of awareness of flood risk (PC2 scores) were significantly higher among subscribers to FWD than among those who had not joined the scheme (U=58882.5; $p<0.001)$. The associations between subscription to FWD or having flood insurance and PC3 (attributed responsibility) were not statistically significant.

\subsection{Flood-protection measures: Current uptake and interest in acquisition}

Nearly $29 \%$ of respondents said that nothing could be done to protect their home from flooding, and $18.6 \%$ suggested sandbags as the only measure they could use. Very few respondents already had flood-protection measures (Table 5), and was exceeded by the number of people not familiar with resistance and resilience measures. However, between a third and over a half of respondents (depending on the product) said they would consider installing these improvements in the future. The most popular flood-protection measure was raising electrical fixtures above the likely water level, whilst only one third said they would consider replacing wooden staircases with concrete ones. The main reason for lack of interest among remaining respondents was perceived absence of need due to low risk of flooding.

Those who said they would consider installing flood-protection measures in the future were significantly younger and were characterised by significantly higher scores for PC1 (awareness of climate change), with the exception of tiled flooring, and PC2 (awareness of flood risk), in comparison to those who were not interested in the improvements (Table 6).

Table 5 Implementation of flood-protection measures (\% respondents; $N=961$ )

\begin{tabular}{|c|c|c|c|c|c|}
\hline & $\begin{array}{l}\text { Door } \\
\text { guards }\end{array}$ & $\begin{array}{l}\text { Air brick } \\
\text { covers }\end{array}$ & $\begin{array}{l}\text { Tiled } \\
\text { floors }\end{array}$ & $\begin{array}{l}\text { Raised electrical } \\
\text { fixtures }\end{array}$ & $\begin{array}{l}\text { Concrete } \\
\text { staircase }\end{array}$ \\
\hline Already done & 6.8 & 2.0 & 6.6 & 8.4 & 3.7 \\
\hline $\begin{array}{l}\text { Considered for the } \\
\text { future }\end{array}$ & 45.8 & 47.9 & 38.6 & 56.6 & 33.6 \\
\hline No knowledge & 10.5 & 15.5 & 5.7 & 8.5 & 8.8 \\
\hline
\end{tabular}


Table 6 Willingness to install the measures in the future (Mann-Whitney test)

\begin{tabular}{llllll}
\hline & $\begin{array}{l}\text { Door } \\
\text { guards }\end{array}$ & $\begin{array}{l}\text { Air brick } \\
\text { covers }\end{array}$ & $\begin{array}{l}\text { Tiled } \\
\text { floors }\end{array}$ & $\begin{array}{l}\text { Raised electrical } \\
\text { fixtures }\end{array}$ & $\begin{array}{l}\text { Concrete } \\
\text { staircase }\end{array}$ \\
\hline $\begin{array}{l}\mathrm{N} \\
\text { PC1: Awareness of climate } \\
\text { change }\end{array}$ & 692 & 694 & 723 & 721 & 722 \\
PC2: Awareness of flood risk & $42580.0^{\mathrm{a}}$ & $44365.5^{\mathrm{a}}$ & $51187.0^{\mathrm{a}}$ & $43344.0^{\mathrm{a}}$ & $53237.0^{\mathrm{a}}$ \\
Age & $49084.0^{\mathrm{a}}$ & $50149.5^{\mathrm{a}}$ & $54558.0^{\mathrm{a}}$ & $54171.5^{\mathrm{b}}$ & $50966.0^{\mathrm{a}}$ \\
\hline
\end{tabular}

${ }^{\mathrm{a}}$ Significant at $0.01 \mathrm{level;}{ }^{\mathrm{b}}$ Significant at 0.05 level; ${ }^{\mathrm{c}}$ Significant at 0.10 level; n.s.- - not significant

Interestingly, the principal component describing how the responsibility for protection of houses against flooding is shared between homeowners and the government was not associated with willingness to implement flood-protection measures in the future. The interest in installing the measures was not associated with social grade.

\subsection{Energy-saving measures: Current uptake and interest in acquisition}

Asked about how they could make their property more energy-efficient, $22 \%$ of respondents said they could not do anything more. Each of the energy-saving measures listed in the questionnaire was present in over 50\% of respondents' houses (Table 7), and the complete set of all listed measures was installed in $23.2 \%$ of properties. Respondents' age, social grade or levels of awareness about climate change were not significantly associated with the current uptake of energy-saving measures.

The older respondents were significantly less likely to consider wall insulation, energysaving appliances or double glazing in the future. Those planning wall insulation, energyefficient boilers or A-rated appliances showed higher levels of awareness about climate change (PC1) (Table 8). Associations with the scores of remaining principal components and social grade were not statistically significant.

\subsection{Preparedness to pay for adaptation and mitigation measures}

Over a third of respondents would not pay anything for either flood-protection or energy-saving measures. The median value of the sum that respondents said they would pay was between $£ 100$ and $£ 500$ for either type of improvement. However, a considerable proportion of respondents said they would pay over $£ 1,000$ to make their houses better prepared for floods $(11.6 \%)$ and more energy-efficient $(13.7 \%$; Fig. 1).

Table 7 Implementation of energy-saving measures (\% respondents; $N=961)$

\begin{tabular}{llllll}
\hline & $\begin{array}{l}\text { Loft } \\
\text { insulation }\end{array}$ & $\begin{array}{l}\text { Wall } \\
\text { insulation }\end{array}$ & $\begin{array}{l}\text { Energy-efficient } \\
\text { boiler }\end{array}$ & $\begin{array}{l}\text { A-rated } \\
\text { appliances }\end{array}$ & $\begin{array}{l}\text { Double } \\
\text { glazing }\end{array}$ \\
\hline $\begin{array}{l}\text { Already done } \\
\begin{array}{l}\text { Considered for the } \\
\text { future }\end{array}\end{array}$ & 75.4 & 52.2 & 58.3 & 61.9 & 85.8 \\
\begin{tabular}{l} 
No knowledge \\
\hline
\end{tabular} & 2.5 & 19.6 & 29.4 & 28.1 & 9.1 \\
\hline
\end{tabular}


Table 8 Willingness to install the measures in the future (Mann-Whitney test)

\begin{tabular}{llllll}
\hline & $\begin{array}{l}\text { Loft } \\
\text { insulation }\end{array}$ & $\begin{array}{l}\text { Wall } \\
\text { insulation }\end{array}$ & $\begin{array}{l}\text { Energy-efficient } \\
\text { boiler }\end{array}$ & $\begin{array}{l}\text { A-rated } \\
\text { appliances }\end{array}$ & $\begin{array}{l}\text { Double } \\
\text { glazing }\end{array}$ \\
\hline $\begin{array}{l}\mathrm{N} \\
\text { PC1: Awareness of climate } \\
\text { change }\end{array}$ & 181 & 355 & 327 & 311 & 110 \\
Age & n.s. & $12211.5^{\text {a }}$ & $7886.5^{\mathrm{b}}$ & $7081.5^{\mathrm{c}}$ & n.s. \\
\hline
\end{tabular}

${ }^{\mathrm{a}}$ Significant at $0.01 \mathrm{level} ;{ }^{\mathrm{b}}$ Significant at 0.05 level; ${ }^{\mathrm{c}}$ Significant at 0.10 level; n.s.- - not significant

The more aware respondents were of climate change and its impacts (high scores of PC1), the more they were willing to pay for both the adaptation and mitigation measures (Table 9). Awareness of flood risk was positively associated with potential expenditure on flood-protection measures. Acceptance of responsibility for flood protection (low scores of PC3) was weakly correlated with the sum to pay for flood-protection measures. Older respondents were prepared to pay less for both mitigation or adaptation improvements, and respondents from social grades $\mathrm{A}$ to $\mathrm{C}$ would pay more for energy-saving measures.

The Mann-Whitney test suggested that those registered with FWD, or those in possession of flood insurance, were inclined to pay slightly more for flood-protection measures (respectively $\mathrm{U}=51864.5 ; p<0.05$ and $\mathrm{U}=19021.0 .0 ; p<0.05$ ).

\section{Discussion}

\subsection{Conditions for further adoption of mitigation measures}

The survey found that a high proportion of respondents reported having energy-saving measures installed in their homes. The uptake of double glazing and cavity wall insulation corresponded well with national figures, whilst the uptake of loft insulation and energyefficient boilers seemed higher than in national studies (DECC 2010a; CLG 2010). This may be due to the wording of the questions, which did not specify the thickness of insulation or the type of boiler that could be regarded as efficient. Nevertheless, the full set of listed energy-saving measures was installed only in a quarter of households, therefore leaving scope for improvement.

Fig. 1 Sum of money (GBP) respondents were prepared to pay for flood-protection and energy-saving measures

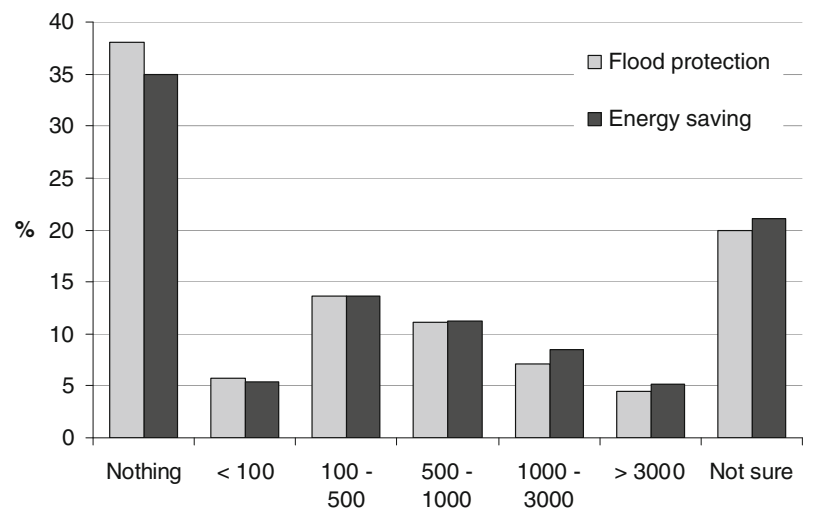


Table 9 Spearman's rank correlation $\left(r_{s}\right)$ between the sum of money the respondents would spend on energy-saving or flood-protection measures, principal components, and characteristics of respondents

\begin{tabular}{lll}
\hline & Flood-protection measures & Energy-saving measures \\
\hline $\mathrm{N}$ & 678 & 671 \\
PC1: Awareness of climate change & $0.195^{\mathrm{a}}$ & $0.186^{\mathrm{a}}$ \\
PC2: Awareness of flood risk & $0.224^{\mathrm{a}}$ & n.s. \\
PC3: Attributed responsibility & $-0.093^{\mathrm{c}}$ & n.s. \\
Age & $-0.128^{\mathrm{b}}$ & $-0.123^{\mathrm{b}}$ \\
Social grade & n.s. & $-0.097^{\mathrm{c}}$ \\
\hline
\end{tabular}

${ }^{\text {a }}$ Significant at 0.01 level; ${ }^{\mathrm{b}}$ Significant at 0.05 level; ${ }^{\mathrm{c}}$ Significant at 0.10 level; n.s. - not significant

The vast majority of respondents were aware that energy used in their homes contributes to climate change, and that limiting its use can mitigate impacts on their homes, which is consistent with the national DEFRA (2009a) survey. The absence of significant differences in awareness of climate change between social grades may suggest that coverage of the issues through various media sources and through governmentsponsored messages and campaigns has been successful in penetrating British society (Lorenzoni et al. 2006).

Also, the low proportion of respondents with no knowledge of energy-saving solutions listed in the questionnaire suggests that the awareness-raising actions carried out, for example, by the Energy Saving Trust, have been successful. The absence of significant differences in uptake of energy-efficiency measures among the respondents from different social grades and age groups goes against the perception that higher social grades are more environmentally conscious and more interested in investing in energy-efficient appliances (Boardman et al. 1997) and may be associated with government actions aiming to increase their affordability (Boardman 2004). It may also suggest that the support offered for households within the Warm Front programme targeting households occupied by the elderly and those in receipt of welfare benefits has been successful (DEFRA, BERR 2008).

Interest in the implementation of energy-saving measures in the future was considerable. Cavity wall insulation was the only measure that did not appeal to the majority of respondents. Whilst the current uptake of energy-saving measures is not associated with awareness of climate change, interest in future implementation was linked to the understanding of the issues. Whilst in the past, a reluctance to spend money on energy conservation could have been explained by an incomplete understanding of the consequences of global warming, DEFRA (2009a) and Lorenzoni et al. (2007) are reporting an increase in awareness of climate change compared to previous studies. The association between higher levels of awareness of climate change and the increased sum of money respondents said they were willing to pay for energy-efficiency measures in this study suggests that education and awareness campaigns have a role to play in motivating the public, but are not sufficient on their own to secure wholesale participation.

Consistent with previous studies, older respondents were less concerned about, and less aware of, climate change. They were also less likely to consider purchasing energy-saving measures. This may be associated with the impacts of climate change being perceived as something that will happen in the future (Whitmarsh 2008). Also, Boardman et al. (1997) report that the elderly are more likely to think that they cannot do anything else to save energy, due to the perception that they already live a thrifty life. This suggests that this group should remain a special target for policy efforts. 
Rather predictably, respondents from lower income households were less inclined to pay for energy-saving measures compared to those with more disposable income. This may reflect the perceived affordability of solutions, as indicated by DEFRA (2009a). Another reason could be the provision of some energy solutions by the Warm Front (DEFRA, BERR 2008), which in the case of poorer homeowners removes the pressure to invest from them.

The median sum of money that respondents were prepared to pay ( $£ 100-£ 500$ ) would be sufficient for one or two energy-efficiency measures. However, in order to buy a more comprehensive set, householders would need to spend considerably more than the sum they stated in the survey. Therefore, in the case of energy-saving measures, some of the necessary conditions for increased uptake, such as awareness of the problem, perceived responsibility for action and awareness of solutions, seem to be in place. However, while rising fuel costs may motivate some low income households to invest in energy measures at current prices, policymakers should continue to find ways to minimise the costs of these materials at the point of purchase.

\subsection{Conditions for adoption of adaptation measures}

The high awareness of living in flood risk areas exceeded that reported in other studies (Harries 2008), despite the fact that only a small proportion of respondents had experienced flooding in the past. This suggests that the EA's approach to informing people about flood risk (EA 2009a) may have been reasonably effective, although the widespread flooding in the summer of 2007 in England and Wales (Pitt 2008) also may have increased awareness of flooding as a potential threat and influenced respondents' answers.

Whilst, as expected, first-hand experience of flooding and awareness of a flood threat were associated with heightened concern about the future (Burningham et al. 2007; Werritty et al. 2007; Kazmierczak and Bichard 2010), the vast majority still perceived the risk as very low or low. This apparent dissonance might stem from a denial that the risk will be realised (Grothmann and Patt 2005). This may create a significant emotional barrier to motivating householders to undertake climate change adaptation work on their houses (Lamond and Proverbs 2009). Also, whilst a majority were aware of FWD (suggesting that the information about the service is adequate to flood-threatened areas), the survey confirmed levels of subscription to FWD identical to those from 2007 (Pitt 2007). This would suggest that whilst the floods in 2007 may have influenced the awareness of flooding as a phenomenon, they did not significantly affect the perceptions of risk. Many respondents did not think that the risk was sufficient to justify subscribing to the free warning service. This suggests that the manner the risk is communicated should be revisited by policymakers and emergency planners.

The numbers of people who declared they were insured against flooding were high, a finding supported by other studies (see Werritty et al. 2007). However, uncertainty around the agreement between government and insurers after 2013 (ABI 2008) may mean that in the future some households may be left without cover. Purchase of flood insurance was less prevalent among lower income households and this, combined with evidence that the poorest households often suffer from the worst post-flood trauma and losses (Tapsell et al. 2002), indicates that authorities should not assume that insurance policies will help all communities to recover from flood events. Further, in some cases, flood-protection insurance may create a barrier to individuals taking responsibility for property-level protection. 
Indeed, the findings - in accord with Terpstra and Gutteling (2008) — suggest that many people are unaware of their personal responsibility in managing flood risk. Moreover, those who have experienced flooding are more inclined to think that the government is responsible for the protection of their property, rather than taking a proactive approach. This suggests that encouraging responsibility for action is a crucial step in increasing the uptake of flood-protection measures by individual householders.

The low numbers of households that have purchased flood resistance and resilience measures suggests that the Environment Agency's efforts to influence homeowners to invest in property-level flood protection do not appear to have been effective to date. Without a prompt, nearly $30 \%$ of respondents thought they could not do anything to protect their home from flooding, and one-fifth considered sandbags as the most adequate protection. Whilst the EA provides some information about available measures in their information leaflet (EA 2009b), as a government body they cannot promote any commercially available products, ${ }^{2}$ and it remains incumbent on householders to research and acquire the best solution for their property. In addition, directing householders to an internet website for more information excludes those with no computer access or skills, such as the elderly and the poor. Further, typical costs for flood-proofing a property, as quoted in the EA brochure, are at least $£ 2,000$, which is beyond the amount (£100-500) that respondents said they would spend.

The perception of climate change and risk of flooding depends on a range of complex individual and social factors (Grothmann and Patt 2005). This study did not test all variables suggested by the behavioural theorists. Recent work on how behaviours might be influenced has been undertaken by, for example, Lorenzoni et al. (2007), Swim et al. (2009), and Whitmarsh et al. (2010). However, the reasoned behaviour model (Ajzen and Fishbein 1980) does provide a useful starting point for policymakers to test whether their strategies are addressing the majority of barriers to owner-occupier action. When applied to the answers given in the attitudinal survey, it is clear that, in the case of flood-protection measures, the only condition that was met was the awareness of the problem of flooding. However, the risks were not seen as sufficient to warrant action. The responsibility attributed to the authorities, the incomplete knowledge of solutions and the reluctance to spend sufficient sums on either energy or flood measures all suggest that there are still significant barriers to overcome before decisions favourable to property-level investment become a mainstream commitment for many homeowners. This suggests that significant informational, emotional and financial barriers need to be overcome to increase the uptake of these measures.

\subsection{Policy implications}

The discrepancy between the acquisition of energy-saving and flood-protection measures clearly illustrates the gap between climate change mitigation and adaptation agendas for house owners. Whilst, in the UK, the need for adaptation to extreme weather and climate changes is increasingly signposted (Evans et al. 2004; Pitt 2008), the national agenda still emphasises action to reduce $\mathrm{CO}_{2}$ emissions, for example through the Climate Change 2008 . The potential increase in floods as a result of climate change (Evans et al. 2004), combined with recently announced cuts in spending on flood defences (ABI 2010) and the impending deadline on provision of flood insurance (ABI 2008), suggest an urgent need to focus on

\footnotetext{
${ }^{2}$ However, the EA signposts the public towards the Kitemark quality assurance scheme for flood products, which was introduced in 2003 and is managed by the British Standards Institution (Johnson et al. 2007).
} 
adaptive actions and to re-assess ways in which to motivate house owners to embrace the idea of investing in individual property measures.

The findings of this study suggest that a continuation of awareness-raising campaigns without the augmentation of additional strategies is not likely to increase the uptake of property-level flood-protection measures. There is a clear need for a shift from informing people that they live in a flood risk area to better communication of the likelihood and ramifications of flooding where they live. This will require clearer and more persuasive arguments about why it is important to subscribe to the warning services, and an explanation of the issues associated with reliance on flood insurance alone.

According to Werritty et al. (2007: 85) public bodies clearly have a major educational task ahead in addressing widely held misconceptions about where the responsibility for flood protection lies. Therefore, there is a need for policy and actions which would emphasise the shared responsibility between homeowners and the government. According to Werritty et al. (2007) and Johnson and Priest (2008), the media and the public still favour structural flood defences. However, it must be communicated that they do not offer $100 \%$ safety and that homeowners must be prepared to act and take a share of the responsibility. The Dutch government has tried to counter this perception with a campaign to show that it is no longer possible to protect the whole population's properties against flood waters. "The Netherlands Live with Water campaign" uses a combination of mass media, including radio and television commercials, newsletters, advertising, information booklets, informative events and a comprehensive website. However, whilst this campaign has been favourably assessed due to the use of the popular media and wellknown media personalities to raise awareness about what can be done by individual homeowners (Bronner et al. 2003), Terpstra and Gutteling (2008) show that a majority of Dutch citizens still relies on the government to protect them. Thus, prior to investing in a major campaign, a significant amount of research into risk communication methods is needed.

The financial barrier (Lamond and Proverbs 2009), represented by the limited amounts of money that homeowners were prepared to invest (particularly the elderly and those with little disposable income), is another significant policy challenge. If the inability to pay for flood-protection measures is compounded by a lack of house insurance then this would place poorer homeowners in flood-threatened areas in a parlous position. One potential solution to overcome limited spending intentions is the provision of government grants (Johnson and Priest 2008). This could be based on the principles employed by the Warm Front programme which provides assistance to residents in receipt of certain state benefits and the elderly (DEFRA, BERR 2008). It should be possible to add an assessment of vulnerability to flooding to expand this means testing process, so that eligibility for both energy conservation and flood protection can be combined into a single grant.

Johnson and Priest (2008) identified some problems associated with flood-protection grants. They observed that heating is perceived as a basic need, whereas the threat of flooding may be seen as an intermittent risk that householders can choose to accept. However, large parts of the population in flood risk areas may have characteristics that preclude them moving away, even if this means accepting higher risk to their property. For example, the elderly can be particularly prone to physical and psychological trauma associated with flooding (DEFRA 2005; Tapsell et al. 2002); they are also the least likely age group to move house (Champion 2005). Therefore, provision of grants for property-level flood-protection measures in their instance could be a reasonable solution. 
While the moral imperative justifies subsidising flood protection for the poorest and oldest householders, the cost of protecting all properties in flood risk areas in England and Wales is prohibitive to widespread state's support. Regarding prioritising of risks, government decisions are largely guided by cost-benefit criteria, and a decision to spend public money to protect some properties but not others could be untenable (Johnson and Priest 2008). Thus, alternative solutions for the remaining population in flood risk areas will need to be devised. Other policy tools that might be deployed could include systems of nointerest loans for flood resistance and resilience products. DEFRA (2005) suggests that an annual repayment plan may be an acceptable mechanism for some. Further, providing homebuyers with information about flood risk and methods of protection should be compulsory. In addition, a revision of the Building Regulations is recommended (Pitt 2008) to ensure that all new or refurbished buildings in high flood-risk areas are equipped to be flood resistant or resilient (DEFRA 2010).

In relation to energy saving, one challenge for policymakers is to overcome the perception that homeowners have already acted sufficiently in response to the problem of climate change (Boardman 2004). While awareness-raising campaigns are beneficial and should be continued, other approaches to motivate homeowners to implement energysaving measures should be pursued. The Royal Institute of Chartered Surveyors (RICS 2010: 4) takes the view that 'the barriers holding back demand are much stronger than the drivers for it, and are primarily behavioural and financial; specifically there is a lack of a reasonable return on capital and an unwillingness to pay high upfront costs for longer term benefits'. Whilst the Warm Front initiative seems to be an efficient vehicle to motivate the acquisition of energy efficiency for the poorest and oldest residents, as it alleviates the costs, for the rest of the population, alternative and complementary strategies are needed.

One approach could be to offer different forms of incentives to invest in property-level measures (Bichard and Cooper 2008). Offering non-cash incentives may overcome the perception that the level of risk does not justify taking action by circumventing the decision-making process entirely. Willingness to accept the reward could be stronger than reluctance to spend money on a non-urgent issue. Bichard and Kazmierczak (2010) in a further study (based on the national survey reported in this paper) tested whether nonfinancial incentives would be acceptable to those planning to invest in energy-saving and flood-protection measures. The rewards that were tested included vouchers for fruit and vegetables and free travel by public transport. The authors found that, whilst cash incentives are the preferred motivation option for respondents, nearly $60 \%$ said they would be motivated to install flood-protection measures if they were offered such non-cash rewards. Thus, sustainable non-cash incentives could have the dual effect of increasing investment in properties and offering the benefits intrinsic to the reward. However, more research is needed on the actual implementation and effectiveness of non-cash incentives.

\section{Conclusions}

This paper has investigated conditions needed to increase implementation of property-level energy-saving and flood-protection measures. It sought to understand levels of awareness of problems related to climate change and apportionment of responsibility for taking action to protect housing against its impacts. It tested knowledge levels about the solutions available to house owners, and their willingness to purchase and install them. The study found that overall adoption rates for energy-saving measures could be seen as a work in progress. Due to good awareness of the problem and the knowledge of solutions, some measures have 
been adopted for the majority of houses. However, for the remaining households cost remains a significant barrier, and should be addressed by public policy. The adoption and knowledge of flood-protection measures is still universally very low, and there is evidence that homeowners do not believe their property is at sufficiently high risk to warrant investment in protection measures. Public policy focused on efficient communication of risk, education about available solutions and provision of material support or other incentives for the poorest and oldest residents of flood risk areas will be needed in the future.

Acknowledgments This research was carried out as part of the Resilient Homes project funded by the Environment Agency. Many thanks go to Professor David Percy (University of Salford), Dr Iain White (University of Manchester) and to the three anonymous reviewers for their insightful comments.

\section{References}

ABI (2008) Revised statement of principles on the provision of flood insurance. Association of British Insurers, London. Available at http://www.abi.org.uk/Publications/Revised_Statement_of_Principles_on the_Provision_of_Flood_Insurance1.aspx Accessed 20 Jan 2011

ABI (2010) Spending Review-ABI comments on flood investment plans. ABI News Release 52/10, 20 October 2010. Association of British Insurers, London

Ajzen I, Fishbein M (1980) Understanding attitudes and predicting social behaviour. Prentice-Hall, Englewood Cliffs, NJ

Bichard E, Cooper CL (2008) Positively responsible. Butterworth-Heinemann, Oxford

Bichard E, Kazmierczak A (2010) Could non-cash rewards motivate homeowners to protect their houses from flooding? In: Kabish S, Kunath A, Feldmann H (Eds), Abstracts of Presentations at 21 International Association of People-Environment Studies Conference: Vulnerability, Risk and Complexity, 27 June2 July 2010 , pp. 273-274

Boardman B (2004) New directions for household energy efficiency: evidence from the UK. Energy Policy 32(17):1921-1933

Boardman B (2007) Home truths: A low-carbon strategy to reduce UK housing emissions by $80 \%$ by 2050 . A research report for the Co-operative Bank and Friends of the Earth. University of Oxford's Environmental Change Institute, Oxford

Boardman B, Lane K, Hinnells M, Banks N, Milne G, Goodwin A, Fawcett T (1997) Transforming the UK cold market. Environmental change institute research report 16. University of Oxford, Oxford

Bowker P (2002) Making properties more resistant to floods. Munic Eng 151:197-205

Bowker P (2007) Flood resistance and resilience solutions: An R\&D scoping study. Environment Agency and Department for Environment, Food and Rural Affairs, London

Bronner F, van der Noort W, Ross R, Tchaoussoglou C (2003) The Netherlands Live with Water-exciting, efficient, effective research. Worldwide Readership Research Symposium, Cambridge, MA

Burningham K, Fielding J, Thrish D (2007) 'It'll never happen to me': understanding public awareness of local risk. Disasters 32:216-238

Champion T (2005) Focus on people and migration: 2005. Chapter 6: Population movement within the UK. Office for National Statistics, London

Clarke JA, Johnstone CM, Kelly NJ, Strachan PA, Tuohy P (2008) The role of built environment energy efficiency in a sustainable UK energy economy. Energy Policy 36:4605-4609

CLG (2010) English housing survey: headline report 2008-2009. Department for Communities and Local Government, London

Climate Change Act 2008. HMSO, London

Crichton D (2007) What can cities do to increase resilience? Phil Trans R Soc 365:2731-2739

DECC (2010a) Statistical release: experimental statistics. Estimates of home insulation levels in Great Britain. Department of Energy and Climate Change, London

DECC (2010b) The Green Deal Energy savings for homes and business public information leaflet 10D/973. Department of Energy and Climate Change, London

DEFRA (2004) Making space for water: Developing a new government strategy for flood and coastal erosion risk management in England: A consultation exercise. Department for Environment, Food and Rural Affairs, London 
DEFRA (2005) The appraisal of human-related intangible impacts of flooding. Department for Environment, Food and Rural Affairs, London

DEFRA (2008a) Developing the evidence base for flood resistance and resilience. R\&D Technical Report FD2607/TR1. Department for Environment, Food and Rural Affairs, London

DEFRA (2008b) Resilience grants pilot projects. Department for Environment, Food and Rural Affairs, London

DEFRA (2009a) Public attitudes and behaviours towards the environment - tracker survey. Department for Environment, Food and Rural Affairs, London

DEFRA (2009b) Government grants to local authorities for household-level flood mitigation. Department for Environment, Food and Rural Affairs, London

DEFRA (2010) Flood and water management bill impact assessment — amendment to the building act to allow building regulations to require flood resilient repair. Department for Environment, Food and Rural Affairs, London

DEFRA, BERR (2008) The UK fuel poverty strategy 6th annual progress report. Department for Environment, Food and Rural Affairs and Department for Business, Enterprise \& Regulatory Reform, London

EA (2009a) Flooding in England. A national assessment of flood risk. Environment Agency, Bristol

EA (2009b) Prepare your property for flooding. A guide for householders and small businesses. Environment Agency, Bristol

EAW (2009) Flood and coastal risk management in Wales. Environment Agency Wales, Cardiff

Evans E, Ashley R, Hall J, Penning-Rowsell E, Saul A, Sayers P, Tjorne C, Watkinson A (2004) Foresight. Future flooding. Scientific summary: Volume 1 - future risks and their drivers. Office of Science and Technology, London

Experian (2009) Mosaic United Kingdom. The consumer classification for the UK. Experian Ltd, Nottingham

Falconer RH, Cobby D, Smyth P, Astle G, Dent J, Golding B (2009) Pluvial flooding: new approaches in flood warning, mapping and risk management. J Flood Risk Manag 2:198-208

Grothmann T, Patt A (2005) Adaptive capacity and human cognition: the process of individual adaptation to climate change. Glob Environ Chang Part A 15:199-213

Harries T (2008) Householder responses to flood risk the consequences of the search for ontological security. $\mathrm{PhD}$ Thesis Middlesex University, London

HM Government (2006) Climate Change- the UK Programme 2006

Jenkins GJ, Perry MC, Prior MJ (2009) The climate of the United Kingdom and recent trends, revised edition. Met Office Hadley Centre, Exeter

Johnson C, Penning-Rowsell E, Parker D (2007) Natural and imposed injustices: the challenges in implementing 'fair' flood risk management policy in England. Geogr J 173:374-390

Johnson C, Priest S (2008) Flood risk management in England: A changing landscape of risk responsibility? Int J Water Resour D 24:513-525

Kazmierczak A, Bichard B (2010) Investigating homeowners' interest in property-level flood protection. Int J Disaster Resilience Built Env 1:157-172

Lamond JE, Proverbs DG (2009) Resilience to flooding: lessons from international comparison. Urban Des Plan 162:63-70

LGDU (2008) Welsh housing statistics 2008. Local Government Data Unit-Wales, Cardiff

Lorenzoni I, Leiserowitz A, Doria M, Poortinga W, Pidgeon N (2006) Cross national comparisons of image associations with 'global warming' and 'climate change' among laypeople in the United States of America and Great Britain. J Risk Res 9:265-281

Lorenzoni I, Nicholson-Cole S, Whitmarsh L (2007) Barriers perceived to engaging with climate change among the UK public and their policy implications. Glob Environ Chang 17:445-459

Meier E, Moy C (2004) Social Grading and the Census. Int J Market Res 46:141-170

Ofgem (2008) A review of the energy efficiency commitment 2005-2008. Report to the secretary of state for environment, food and rural affairs. Office for Gas and Electricity markets, London

ONS (2001) Census 2001. Office for National Statistics, London

Palmer TN, Räisänen J (2002) Quantifying the risk of extreme seasonal precipitation events in a changing climate. Nature 415:512-514

Parker DJ, Tunstall SM, McCarthy S (2007) New insights into the benefits of flood warnings: Results from a household survey in England and Wales. Env Hazard 7:193-210

Pitt M (2007) Learning lessons from the 2007 floods, an independent review by Sir Michael Pitt. Interim report, Cabinet Office, London

Pitt M (2008) Learning lessons from the 2007 floods, an independent review by Sir Michael Pitt. Cabinet Office, London 
RICS (2010) Energy efficiency and value project: Final report. Royal Institution of Chartered Surveyors, London

Sanders CH, Phillipson MC (2003) UK adaptation strategy and technical measures: the impacts of climate change on buildings. Build Res Inf 31:210-221

Smith JB, Schneider SH, Oppenheimer M, Yohe GW, Hare W, Mastrandrea MD, Patwardhan A, Burton I, Corfee-Morlot J, Magadza CDH, Füssel H-M, Pittock AB, Rahman A, Suarez A, van Ypersele J-P (2009) Assessing dangerous climate change through an update of the Intergovernmental Panel on Climate Change (IPCC) "reasons for concern". P Natl Acad Sci USA 106:4133-4137

Stern P (2000) Towards a coherent theory of environmentally significant behaviour. J Soc Issues 56:407-424

Swim J, Clayton S, Doherty, T, Gifford R, Howard, G, Reser, J, Stern P, Weber E (2009) Psychology \& Global Climate Change: addressing a multifaceted phenomenon and set of challenges. A report of the American Psychological Association Task Force on the Interface Between Psychology \& Global Climate Change. Available at http://www.apa.org/science/about/publications/climate-change.aspx Accessed 31 Jan 2011

Tapsell SM, Penning-Rowsell EC, Tunstall SM, Wilson TL (2002) Vulnerability to flooding: health and social dimensions. Philos T R Soc A 360:1511-1525

Terpstra T, Gutteling JM (2008) Households' perceived responsibilities in flood risk management in the Netherlands. Int J Water Resour D 24:555-565

Three Regions Climate Change Group (2008) Your home in a changing climate: retrofitting existing homes for climate change impacts. Greater London Authority, London

WAG (2010) State of the environment. Welsh Assembly Government, Cardiff

Werritty A, Houston D, Ball T, Tavendale A, Black A (2007) Exploring the social impacts of flood risk and flooding in Scotland. The Scottish Government, Edinburgh

Whitmarsh L (2008) Are flood victims more concerned about climate change than other people? The role of direct experience in risk perception and behavioural response. J Risk Res 11:351-374

Whitmarsh L, O’Neill S, Lorenzoni I (2010) Engaging the public with climate change: Behaviour change and communication. Earthscan, London

Wilmhurst J, McKay A (1999) The fundamentals of advertising. Butterworth-Heinemann, Oxford 